慶應義塾大学学術情報リポジトリ

Keio Associated Repository of Academic resouces

\begin{tabular}{|c|l|}
\hline Title & Development of an optical-fibre sensor using a functional membrane \\
\hline Sub Title & \\
\hline Author & 高井, 信治(Takai, Nobuharu) \\
& $\begin{array}{c}\text { 平井, 利志(Hirai, Toshiyuki) } \\
\text { 佐久間, 一郎(Sakuma, Ichiro) } \\
\text { 福井, 康裕(Fukui, Yasuhiro) } \\
\\
\text { 金子, 明子(Kaneko, Akiko) } \\
\text { 藤江, 忠雄(Fujie, Tadao) }\end{array}$ \\
\hline Publisher & 共立薬科大学 \\
\hline Publication year & 1993 \\
\hline Jtitle & 共立薬科大学研究年報 (The annual report of the Kyoritsu College of \\
& Pharmacy). No.38 (1993. ),p.87-87 \\
\hline JaLC DOI & \\
\hline Abstract & \\
\hline Notes & 抄録 \\
\hline Genre & Technical Report \\
\hline URL & https://koara.lib.keio.ac.jp/xoonips/modules/xoonips/detail.php?koara_id=AN00062898-0000003 \\
\hline & $8-0087$ \\
\hline
\end{tabular}

慶應義塾大学学術情報リポジトリ(KOARA)に掲載されているコンテンツの著作権は、それぞれの著作者、学会または出版社/発行者に帰属し、その権利は著作権法によって 保護されています。引用にあたっては、著作権法を遵守してご利用ください。

The copyrights of content available on the KeiO Associated Repository of Academic resources (KOARA) belong to the respective authors, academic societies, or publishers/issuers, and these rights are protected by the Japanese Copyright Act. When quoting the content, please follow the Japanese copyright act. 


\title{
Development of an Optical-fibre Sensor Using a Functional Membrane*
}

\author{
Nobuharu TAKaI**, Toshiyuki HiraI ${ }^{* * *}$, Ichiro SAKUmA ${ }^{* * *}$, Yasuhiro FuKUI ${ }^{* * *}$, \\ Akiko Kaneko and Tadao FujIE \\ 高井信治**, 平井利志 ${ }^{* *}$, 佐久間一郎 ${ }^{* *}$, 福井康裕 ${ }^{* * *}$, 金子明子, 藤江忠雄
}

A new functional membrane which changes its reflectance spectra according to the $\mathrm{pH}$ of the test solution is described. A chloromethylstyrene (CMS)/methylmethacrylate (MMA) copolymer was chosen as the base for the immobilized reagent. A basic ion-exchanger was then added the CMS/MMA copolymer. Bromothymol Blue (BTB) was then immobilized on the copolymer. A functional membrane could then be fabricated in various shapes since chemical modification of CMS/MMA copolymer could be performed before casting. The fabricated $\mathrm{pH}$ sensitive functional membrane showed a maximum reflectance change at the wavelength of $540 \mathrm{~nm}$ for $\mathrm{pH}$ changes from 4.0 to 9.0. Dissolution of BTB from the CMS/MMA copolymer was minimal so that good reproducibility of the reflectance change was obtained.

* 本報告は Sensors and Acutuators B. 13-14，427-428（1993）に発表。

** 東大 ・生産研

*** 東京電機大 